\title{
Klaudia Cymanow-Sosin
}

Uniwersytet Papieski Jana Pawła II w Krakowie

\section{O KOMUNIKOWANIU SPOEECZNYM W DOBIE NOWYCH TECHNOLOGII. SPRAWOZDANIE Z KONGRESU THE SOCIAL COMMUNICATION} IN THE ERA OF NEW TECHNOLOGIES

IV Kongres Polskiego Towarzystwa Komunikacji Społecznej w Poznaniu Komunikowanie społeczne $w$ dobie nowych technologii, Poznań, Uniwersytet Adama Mickiewicza, 14-17 września 2016 roku

Polskie Towarzystwo Komunikacji Społecznej, powołane w 2008 roku jako efekt dyskusji podczas konferencji podsumowującej półwiecze badań nad komunikowaniem i mediami w Polsce, zorganizowało w dniach 15-17 września 2016 roku IV Kongres PTKS Komunikowanie społeczne $w$ dobie nowych technologii. Była to okazja do prezentacji własnych badań, prowadzenia publicznej debaty i wreszcie integracji polskiego środowiska medioznawczego. Jak podkreślali organizatorzy, zapraszając do udziału w tym wydarzeniu: „Technologia wkroczyła już w prawie każdy obszar ludzkiego życia. Nie mogła ominąć jednego z najważniejszych - komunikowania”.

Minęły już trzy lata od poprzedniego kongresu, który miał miejsce w Krakowie. Przypomnijmy, że to właśnie w naszym mieście od 26 do 28 września 2013 roku odbywał się III Kongres Polskiego Towarzystwa Komunikacji Społecznej pod hasłem Mediatyzacja $\dot{z} y c i a, k u l t u r y$, polityki. Co warto szczególnie podkreślić, podówczas współorganizatorami kongresu były Instytut Dziennikarstwa i Komunikacji Społecznej - Wydział Zarządzania i Komunikacji Społecznych UJ oraz Instytut Dziennikarstwa i Komunikacji Społecznej Uniwersytetu Papieskiego Jana Pawła II w Krakowie, honorowymi patronami byli rektorzy obu uczelni, a istotnym społecznie tematem przewodnim - zjawisko mediatyzacji, czyli szerokich, wielokierunkowych wpływów i oddziaływań mediów na treści i formy życia społecznego. 
Kongresy Polskiego Towarzystwa Komunikacji Społecznej odbywają się co trzy lata i stanowią jedno z najważniejszych wydarzeń dla badaczy z dziedziny komunikowania masowego.

Tym razem miejscem spotkania było Centrum Kultury Zamek w Poznaniu. Organizatorzy i uczestnicy podkreślali aktywność Towarzystwa na polu badawczym, ale i ważną dla zainteresowanych integrację rozproszonego środowiska naukowców i praktyków komunikowania, a także troskę o uporządkowanie obszaru studiów nad komunikowaniem i mediami w Polsce, starania o podniesienie ich rangi i poziomu oraz współpracę pomiędzy podobnymi towarzystwami krajowymi i zagranicznymi. Jednym z nadrzędnych celów władz i członków PTKS jest także dążenie do wyodrębnienia nauki o mediach i komunikacji jako autonomicznej dyscypliny naukowej, czego wyrazem była m.in. uchwała PTKS w sprawie umieszczenia dyscypliny nauki o mediach w panelu HS5 w wykazie Narodowego Centrum Nauki.

Zaproszeni goście podczas licznych spotkań i sesji badawczych oraz w trakcie obrad plenarnych dyskutowali nad tym, w jaki sposób nowe technologie wpływają na istotę i jakość komunikowania. Jednym z kluczowych zagadnień była także rola środków i sposobów komunikowania w obliczu zmian kulturowych.

IV Kongres PTKS rozpoczął się od uroczystego powitania gości z Polski i z zagranicy, którego dokonała prof. zw. dr hab. Iwona Hofman (Uniwersytet Marii Curie-Skłodowskiej), Prezes Polskiego Towarzystwa Komunikacji Społecznej.

Wręczono nagrody kapituły Konkursu „Doktorat” na najlepszą rozprawę doktorską o komunikowaniu i mediach oraz za najlepszą monografię naukową z dziedziny nauk o mediach i komunikowaniu. Prof. dr hab. Bogusława Dobek-Ostrowska oraz dr Michał Głowacki przedstawili perspektywy czasopisma naukowego PTKS „Central European Journal of Communication” oraz serii Political Communication wydawnictwa Peter Lang.

Co szczególnie warte podkreślenia, w części III sesji plenarnej In memoriam naukowcy wspominali dwie postaci. Pierwsza z nich to prof. Wolfgang Donsbach, a druga to o. prof. Leon Dyczewski, o którym pięknie mówili ks. dr hab. Michał Drożdż, prof. UPJPII i dyrektor Instytutu Dziennikarstwa i Komunikacji Społecznej Uniwersytetu Papieskiego Jana Pawła II oraz prof. Jerzy Olędzki, dyrektor Instytutu Edukacji Medialnej i Dziennikarstwa na Wydziale Teologicznym Uniwersytetu Kardynała Stefana Wyszyńskiego w Warszawie.

Byliśmy także uczestnikami ciekawych sesji plenarnych. Swoimi spostrzeżeniami podzieliło się z audytorium sześciu mówców: prof. Barbara Pfetsch z Freie Universität Berlin, dr Václav Štětka z Charles University in Prague, prof. Bogusława Dobek-Ostrowska z Uniwersytetu Wrocławskiego oraz Richard Hornik z Stony Brook University, USA, który z mgr Agnieszką Filipiak i mgr Elizą Kanią z UAM zaprezentowali międzynarodowy projekt News Literacy for Civil Society in XXI century.

Celem wymiany myśli były także rozważania nad stanem pracy poszczególnych sekcji badawczych. Tę cześć spotkania prowadził także ks. dr hab. Michał Drożdż, prof. UPJPII, przewodniczący sekcji aksjologii komunikowania PTKS. W trakcie odbywających się sesji podkreślano m.in. udaną współpracę z naukowymi towarzystwami międzynarodowymi (ICA, ECREA, IPSA, IAMCR) czy badaczami i uczelniami z Europy Środkowej, a także wspieranie działalności wydawniczej. 
Kolejne dni to czas spotkań w siedzibie kampusu Morasko, gdzie mieści się Wydział Nauk Politycznych i Dziennikarstwa Uniwersytetu Adama Mickiewicza. Tematem przewodnim było Komunikowanie społeczne $w$ dobie nowych technologii. Kilkuset naukowców $\mathrm{z}$ różnych ośrodków akademickich z całego kraju, a także z zagranicy, m.in. Czech, Niemiec czy Stanów Zjednoczonych, brało udział w kilkudziesięciu panelach naukowych, dyskusjach oraz wyborze nowego zarządu. Jak stwierdzili naukowcy, pomimo wielu możliwości, jakie oferują nowe technologie, współczesne media i szybkie kanały komunikacji, okazuje się, że nic nie zastąpi rozmowy twarzą w twarz, bezpośredniej wymiany idei i własnych doświadczeń. Konkluzja ta była także zwieńczeniem debaty w sekcji aksjologicznej, najliczniej reprezentowanej przez pracowników naszego uniwersytetu.

Wśród prelegentów nie zabrakło dużej reprezentacji Instytutu Dziennikarstwa i Komunikacji Społecznej na Wydziale Nauk Społecznych Uniwersytetu Papieskiego Jana Pawła II w Krakowie. Swoje referaty wygłosili: ks. dr hab. Michał Drożdż, prof. UPJPII, dr hab. Krzysztof Gurba, dr Klaudia Cymanow-Sosin, dr Katarzyna Drąg, dr Dorota Narewska, ks. dr Sławomir Soczyński, dr Jakub Żurawski i mgr Bernadeta Cich. Nasze uczestnictwo było podyktowane przede wszystkim troską o wpływ na oddziaływanie mediów w przemianach, jakie dokonują się w ostatnich latach w naszym społeczeństwie. Zmiany w technologiach komunikacyjnych - czego doświadczają nie tylko badacze, ale i użytkownicy mediów, mają olbrzymi wpływ na praktykę komunikowania społecznego. Prowadząc badania nad tymi zjawiskami, naukowcy mogą wskazywać i prognozować procesy determinujące obszar współczesnej komunikacji społecznej. Wyposażeni w taką wiedzę jesteśmy w stanie wspomagać naszych studentów w procesie mediatyzacji, która jest nieodzownym aspektem życia tak zawodowego, jak i prywatnego przyszłych dziennikarzy i specjalistów z zakresu komunikacji. Takie spotkania jak Kongres Polskiego Towarzystwa Komunikacji Społecznej stwarzają możliwość prezentacji dotychczasowych wyników badań, ale także są platformą wymiany refleksji poświęconej komunikowaniu społecznemu w dobie nowych technologii. W jednym miejscu i o jednej porze unaoczniają się różne perspektywy i podejścia badawcze. Pracownicy UPJPII prezentowali się przede wszystkim w tych obszarach, które dotyczyły kwestii etycznych i teorii wartości we współczesnych naukach o mediach - zarówno w dziennikarstwie, public relations, jak i szeroko rozumianej komunikacji społecznej. Zastanawialiśmy się, czy rozwój nowych technologii to całkiem nowa jakość w komunikowaniu, czy tylko kolejny ze środków czy narzędzi porozumiewania się. Istotą namysłu sekcji aksjologicznej była także refleksja nad tym, jakiego typu relacje tworzą się pomiędzy uczestnikami takiego procesu komunikowania. Różne stanowiska prezentowane przez uczestników tej sekcji najpełniej podsumował ks. Michał Drożdż, podkreślając znaczenie dobra wspólnego na różnych poziomach i platformach komunikacji.

Podczas IV Walnego Zjazdu Wyborczego w drugim dniu kongresu zostały wybrane także władze PTKS. Prezesem na kolejną kadencję została wybrana prof. Iwona Hofman, reprezentująca Uniwersytet Marii Curie-Skłodowskiej w Lublinie. W skład zarządu weszli: prof. dr hab. Zbigniew Oniszczuk (wiceprzewodniczący, UŚ), prof. dr hab. Michał Drożdż (skarbnik, UPJPII), dr Małgorzata Adamik-Szysiak (sekretarz, UMCS), prof. dr hab. Bogusława Dobek-Ostrowska (redaktor naczelny „Central European Journal of Communication”, UWr) oraz członkowie - prof. dr hab. Dorota Piontek (UAM), 
prof. dr hab. Alicja Jaskiernia (UW), prof. dr hab. Małgorzata Molęda-Zdziech (SGH). W składzie komisji rewizyjnej znaleźli się dr Bartłomiej Łódzki (przewodniczący, Collegium Da Vinci), dr hab. Beata Klimkiewicz (UJ), dr Monika Kaczmarek-Śliwińska (Politechnika Koszalińska), dr Małgorzata Łosiewicz (UG) oraz dr Mirosława Wielopolska-Szymura (UŚ).

Do składu nowego zarządu już po raz kolejny został wybrany ks. dr hab. Michał Drożdż, prof. UPJPII, któremu w imieniu społeczności uniwersyteckiej serdecznie gratulujemy zaufania, jakim obdarzyli go członkowie PTKS, i życzymy powodzenia w pracach nad rozwojem Towarzystwa.

W Kongresie wzięło udział 290 uczestników i gości. W 52 panelach tematycznych wygłoszono 251 referatów. Prezentowane były wystąpienia o charakterze teoretycznym, raporty z badań oraz analizy przypadków. Na ich podstawie toczone były dyskusje na temat sposobów i technik badania wpływu rozwoju technologicznego na zjawiska w obrębie komunikacji społecznej. Tych kilka dni spędzonych w Poznaniu w połowie września br. stanowiło dla uczestników możliwość konfrontacji swoich przemyśleń na temat mediów i ich kondycji. Z pewnością przyczyni się to do jeszcze silniejszej integracji środowiska medioznawczego. 